\title{
Exploring Citizens' Perceptions-based Intangible Resources in the Public Sector: An Analysis of the Relation Between Wealth and Engagement and Trust in 17 Countries
}

\author{
Paloma Piqueiras \\ (iD) 0000-0002-1485-8812 \\ Complutense University of Madrid, Spain \\ María José Canel \\ 0000-0002-5048-124X \\ Complutense University of Madrid, Spain
}

\begin{abstract}
Across the globe, public administrations are employing communication to develop programs to respond to the challenges of bringing society to the core of policy making and of searching for innovative ways to generate growth. But how much do these programs achieve, and to what extent are their consequences positive? Building on theorizing about intangible assets in the public sector and based on economic indicators as well as on survey data from 17 countries, this paper explores whether specific intangible assets that are citizens' perceptions-based can operate as sources of growth. More specifically, the article looks at citizen engagement and trust, intangible resources that are built upon organizational behaviors as well as activated through communication. Results allow us to compare the relation of these resources with growth with the relation of tangible capital with growth in 17 countries. Based on findings, the article discusses implications for public sector communication.
\end{abstract}

KEYWORDS: public sector communication, intangible capital, intangible asset, engagement, trust.

\section{INTRODUCTION: INTANGIBLE CAPITAL AND WEALTH}

Across the globe, public administrations are facing the challenge of placing their societies at the core of policymaking. In a context, in which resources are becoming scarcer, they are being challenged to look at value differently (Bryson et al., 2015), as well as to search for innovative ways to foster growth 
(Canel \& Luoma-aho, 2019). This paper assumes that the intangible dimension of capital might provide an innovative approach to fostering growth, and it focuses on public sector communication capacity to build intangible value by their fostering citizen engagement and their behaving in a trustworthy manner.

But how much do governmental programs focused on intangible capital achieve, and to what extent are their consequences positive? The literature documents mixed results, and the debate centers in part on the high costs that programs of this kind entail (see, for instance, Denhardt \& Denhardt, 2015; Coursey et al., 2012). Do public sector's intangible assets built through communication provide access to tangible wealth? This is the question that this paper addresses.

Debate about the relationship between intangible capital and growth was triggered by the World Bank when, via two well-known (not to mention controversial) reports, it posed questions about the drivers of nations' wealth (World Bank, 2006, 2011). The bank's conclusion was blunt: intangible capital was a significant factor in influencing growth in all the countries analyzed in the report and accounted for 60-80 percent of total wealth.

The relevance of this finding can be explored from different angles. In this paper, two such angles are highlighted. First, the question of policy consequences is considered: What does the World Bank's finding imply for governance and policymaking? The reports found that most of a country's wealth corresponds to intangible capital, and this was found to be the case especially for rich countries. They even found that intangible capital was the only significant factor of production in OECD countries, which suggests that strategies for creating wealth should be oriented toward the generation of intangible capital. But what is intangible capital exactly, and what produces it?

The causes and sources of intangible capital are the second salient dimension that will be examined here. This issue is particularly important in the case of intangible capital that depends on relations between public sector organizations and citizens. In the World Bank's reports, intangible capital was conceptually described in terms of human capital (the skills and know-how embodied in the labor force) and social capital (the "trust among people in a society and their ability to work together for a common purpose") (World Bank, 2006, XVIII).

These two reports certainly raise questions about the way in which capital is measured, and they were probably the first warning issued at a worldwide level that elicited awareness about what is driving growth in the twenty-first century, and they raise important questions about policymaking. As the second report states, "As long as intangible capital is a black box, governments may be tempted to conclude that all public expenditures that exclude physical infrastructure are in some sense investments in intangible wealth" (World Bank, 2011: 102).

This paper attempts to explore that "black box". It seeks to identify specific assets that: a) can be built by public sector organizations; b) are assets that 
lay on perceptions (stakeholders' acknowledgement) activated via communication; c) might have a relation with growth. Building on theorizing about intangible assets in the public sector (Canel \& Luoma-aho, 2015 and 2019), this paper explores intangible capital from the perspective of the "intangible asset" concept, and more specifically, from that of intangible assets that are based on citizens' perceptions to say, on the capacity of organizations to make their publics acknowledge their strengths. Based on survey data from 17 countries, it explores whether specific public sector intangible assets such as engagement and trust can operate as sources of growth.

The structure of the paper is as follows. Its aims, research questions, and methodology will be presented in the next section. A theory-focused section then follows, in which the paper discusses the role of communication in generating intangible capital, and builds on the concept of intangible assets to elaborate on the meaning of engagement and trust. In the final part of the paper, we present data on the wealth and intangible and tangible capital of 17 countries. Based on the theorizing from the previous section, we then analyze the data to examine differences between strong economies and weaker ones in terms of the weight of intangible assets and its effects on national wealth. Finally, suggestions are provided to improve public sector communication.

\section{RESEARCH QUESTIONS}

This research attempts to:

1. Ascertain whether a relationship between intangible assets and growth can be established, and if so, compare that relationship with that between tangible capital and growth.

2. Collect cross-country comparative data to verify the differences and similarities that exist between wealth data and citizens' perceptions of public sector organizations.

3. Provide governments, policymakers, and public sector professionals with baselines for public policies that increase public administrations' capacity to build intangible capital via communication and, potentially and as a consequence, tangible wealth.

The research questions explored in this article are:

- What aspects of intangible capital show a relationship with wealth?

- What is the relationship between wealth and citizen-perception-based intangible assets as compared to the relationship between wealth and tangible capital?

- Are there differences between strong economies and less strong ones in what regards the relationship of intangible and of tangible capital with wealth? 
- What do the findings from empirical observation reveal about the practical implications of public administrations' development of intangible assets via communication?

\section{BUILDING INTANGIBLE CAPITAL THROUGH PUBLIC SECTOR COMMUNICATION}

This paper builds on a previous definition of intangible assets in the public sector context (Canel and Luoma-aho, 2019, p. 77) to place emphasis on two assumptions. First, an intangible asset enables access to tangible assets. Second, the existence of certain intangible assets is conditional upon the existence of acknowledgement of those assets (somebody has to attribute a given intangible asset to an organization). This implies that intangible assets require communication if they are to be developed (we take a concept of public sector communication which includes the one carried out inside organizations and between organizations and stakeholders, and thus, it also includes public administration communication). Therefore, key to the assets that are analyzed in this paper is the role communication has in activating stakeholders' acknowledgment of them, and thus we understand they are perceptions-based assets. Those intangible assets which are not communication-dependent, such as patents, are disregarded in this paper.

In exploring perceptions-based intangible assets, it should be taken into account that citizens' perceptions of public sector organizations are usually negative, especially due to excessive bureaucracy, inefficiency and corruption (Luoma-aho, 2008); and that the judgments issued by citizens do not respond to a cause-effect relationship, but are the result of a complex dynamic influenced, among other reasons, by their satisfaction with public policies, the communication and information they obtain, and trust (Van de Walle \& Bouckaert, 2003; Carmeli \& Tishler, 2005; James, 2009, 2010, 2011; James \& Moseley, 2014; Sanders \& Canel, 2015).

Finding a relation between wealth and these kind of perceptions-based intangible assets would lead to rethinking organizational and communication culture, and also to derive implications for the practice of public sector communication. In previous research some of these implications were discussed (Canel et al., 2020), and we bring here part of that discussion to frame the role communication might play in developing growth. Intangible assets derive from good practices and experiences, and so although such assets can be managed, they cannot be created from scratch; they have to be supported by actual experiences. This means that intangible assets are activated through both organizational behavior as well as sense-making, and that a culture of deeds-based messages need to be developed. Being oriented to intangible assets fosters a citizen-centered 
culture, and thus the communication that is activated focuses not on impressions management but on relations (for these are assets that cannot be built without a relational approach).

Several practices are inspired by this approach, among which the following can be mentioned. First, building intangible assets requires a detailed knowledge of stakeholders' needs and expectations, which only can be discovered through ongoing interaction with those stakeholders. Second, building intangible assets requires an approach to communication that is strategic, with measures of intangible assets informing decision making and helping organizations to improve performance. Third and as a consequence, new quality criteria would be needed for assessing outcomes, and the evaluation of communication performance would thus be focused on the quality of established relations and on the extent to which citizens are engaged.

\section{BREAKING INTANGIBLE CAPITAL DOWN INTO DIFFERENT ASSETS IN THE PUBLIC SECTOR}

In the "black box" of intangible capital, this paper focuses on those intangible assets that derived from searching those survey items which, according to the literature, seemed to show a logic relation with a concept that referred to a specific intangible asset in the public sector. Those were engagement and trust. The theoretical basis for each of these will now be discussed.

\section{CITIZEN ENGAGEMENT}

Engagement is an intangible asset that, in broad terms, refers to what citizens do within public life or the public sphere. Globally, citizen engagement has become a central aim of public policy and practice, based on the assumption that involving those who are served is a key prerequisite for a blooming society (Fung, 2015). But research provides mixed evidence about how engagement operates, and this paper attempts to look specifically at how it is related to the tangible growth of a country. One of the critical issues in engagement research has to do with what should be taken as expressions of civic engagement, and hence with how to measure it (see, for instance, Teorell et al., 2007; Ekman \& Amna, 2012). In an attempt to go beyond a "classic approach" such as that of Putnam (1995), for whom "civic engagement" includes explicit behaviors such as voter turnout and attendance at public meetings, researchers have attempted to produce wider typologies that see engagement in "latent forms of participation" such as citizens' involvement in the public sphere through organizations other than political ones (Teorell et al., 2007; Dahlgren, 2009; Ekman \& Amna, 2012). 
This distinction is parallel to that of what we call 'political' versus 'public' engagement. There is literature that claims that a political nature of engagement ("the action of ordinary citizens aimed at influencing some political outcomes" (Brady, 1999, p. 737) with expressions such as contacting political representatives, should be differentiated from actions that seek the benefit of the community through solidarity behaviours, such as recycling or donating organs; political participation should be differentiated from public participation (Wang \& Wart, 2007), and thus, 'public engagement' should be differentiated from 'political engagement'. The reason why this is relevant is because, some authors argue, only if research makes this differentiation, it will be possible to capture the engaged citizen of today who might be moving away from the political character and is approaching a more nonpartisan or public commitment (Dalton, 2008; Dahlgren, 2009). If this "new" engagement is identified and measured, governments will be better equipped to foster and deal with it.

Based on the results of the literature review, and using the available items in existing surveys that contain data for OECD countries, in this paper two items are taken from the European Social Survey and the Eurobarometer as politic forms of engagement: 1) During the last 12 months, have you worked in a political party or action group? 2) During the last 12 months, have you contacted a politician, government or local government official? Both items involve questions that elicit binary responses (yes or no). Another two items were taken as public forms of engagement: 1) During the last 12 months, have you signed a petition? 2) Have you done any of the following for the environmental reasons in the past month? Separated most of your waste for recycling. Answers to these questions were given using a binary scale (yes or no).

Although there is a growing body of literature that documents the positive outcomes of engagement arising from the direct involvement of citizens in the assessment of needs and in deliberation over practical solutions (Yang and Barrett and Brunton-Smith, 2014; Fledderus, Brandsen and Honingh, 2015), little work has been done to explore the relationship between engagement and growth.

\section{TRUST}

Literature on trust is huge, for huge is the amount of aspects and angles that can be deployed to observe the phenomenon of (dis)trusting (for an updated discussion on the concept and measures see Oomsels \& Bouckaert, 2014; Oomsels et al, 2019). The specific interest of this research is, on the one hand, to explore how trust as an intangible asset is related with other intangible assets, and here the focus is on engagement. Evidences are mixed. There is an overall consensus attributing benefits to citizens and communities as result of citizen engagement (Denhardt \& Denhardt, 2015; Coursey et al., 2012). It is argued, for 
instance, that this intangible resource increases citizen trust in governments, legitimacy, and social capital (Coursey et al., 2012; Denhardt \& Denhardt, 2015; Heikkila \& Isett, 2007; Yang \& Pandey, 2011). However, there is also research which shows skepticism about the impact of engagement on trust, due to the suspicion generated by governmental messages that citizens see as partisan and with electoral interests (Sanders \& Canel, 2015); to the lower quality of the public services that derive from coproduction (Bovaird \& Loeffler, 2012); and to frustrated expectations (Font \& Navarro, 2013). The second aspect of interest is the relation between the intangible asset of trust and tangible growth, about which literature is very scarce.

Interestingly, the European Social Survey does not include items that relate to trust in the public sector or more specifically to trust in public services or in public administration. The closest items that were pertinent to the present study were assessments made on a ten-point scale of individual trust in public institutions such as parliament, the legal system, the police, and politicians.

\section{METHODOLOGY}

The methodology combines theory-based research with empirical data. The theory part builds on the concept of intangible assets, and more specifically, it considers engagement and trust as possible intangible assets, built through communication, that explain wealth. Literature was reviewed with the objective of identifying what could be useful to measure a specific intangible asset.

Two sets of empirical data are used in this study. First data produced by the World Bank on growth. Variables regarded as measures of tangible capital include GDP per capita, the unemployment rate (which measures the productive potential of an economy) and inflation rate (which provides information about the purchasing power of the population). Second, data from the European Social Survey are used to measure intangible assets. Since this paper deals with intangibles that are grounded in citizens' perceptions (Canel \& Luoma-aho, 2019), the survey data that the article draws on centers on citizens' judgments about public sector organizations. The data relate to 2014 (this is the most recent available data provided in the conditions that this research requires) and cover 17 countries. Items were reviewed with the aim of identifying what could be of use to measure a specific intangible asset of the following two: engagement and trust.

Data were collected and treated with SPSS software. Pearson correlations were deployed to explore the relations between growth (GDP) and tangible capital (unemployment and inflation rates) comparatively with relations between growth (GDP) and intangible capital (engagement and trust). These correlations were conducted with each specific item, and all the variables with a correlation 
over 0.4 have been selected. In addition, the level of significance (bilateral) was determined. Following the standard criteria, the statistical significance (bilateral) was considered to be $\mathrm{p}<0.01$ or $\mathrm{p}<0.05$.

In order to establish comparisons among countries, information referring to intangible assets was synthesized: a factor analysis was carried out including the variables that could yield an indicator of a specific angle of intangible value. Variables were thus grouped following a logic that derived from the literature review on the concepts.

Finally, for comparing countries, the 17 analysed countries were clustered according to their income level, and two groups emerged: stronger economies and weaker economies. Values for the variables are in Annex 1.

\section{FINDINGS}

The results are reported in the following order: an examination of data looking at each specific item that compose each intangible asset; an elaboration of an indicator for each asset which allows for comparisons; an overall comparison between tangible capital and intangible capital; and finally, a comparison of the data on the groups of countries.

\section{ENGAGEMENT AND WEALTH}

Table 1 shows the specific correlations for items that measure engagement.

Table 1. Engagement and GDP (correlations)

\begin{tabular}{c|c|c|c}
\hline & Variables & GDP correlation & Significance (bilateral) \\
\hline $\begin{array}{c}\text { Expressions } \\
\text { of political } \\
\text { engagement }\end{array}$ & Having worked for a political party & 0,433 & 0,083 \\
\cline { 2 - 4 } & $\begin{array}{c}\text { Having contacted a politician } \\
\text { or a government official recently }\end{array}$ & $0,899^{* *}$ & 0,000 \\
\hline $\begin{array}{c}\text { Expressions } \\
\text { of public } \\
\text { engagement }\end{array}$ & Having signed petitions & $0,641^{* *}$ & 0,006 \\
\cline { 2 - 3 } & Having recycled & $0,530^{\star}$ & 0,029
\end{tabular}

Source: own elaboration with data from the World Bank, the ESS and the Eurobarometer

** Correlation is significant at level 0,01

${ }^{*}$ Correlation is significant at level 0,05

The results show that, overall, there is a strong association between GDP and items that measure citizen engagement. Almost all correlations with all the items measuring engagement are high and all, except from "having worked for a political party" are statistically significant; all are positive. The results reported in Table 1 allow to look at the relation between engagement and GDP 
differentiating somehow 'political engagement' from 'public engagement': items referring to more social forms of engagement (such as "having signed petitions" or "having recycled") have a stronger correlation than items that question about political behaviors (such as "having worked for a political party" or "having contacted a politician or government official"). Overall, these data allow to state that the more engaged citizens in a given country are, the higher the country's GDP. The wording of this relationship could be reversed: citizens from high-GDP countries tend to be more engaged in politics, and this issue of causality will be discussed later on.

\section{TRUST AND WEALTH}

Table 2 shows the specific correlations for the items that measure trust.

Table 2. Trust and GDP (correlations)

\begin{tabular}{c|c|c}
\hline Variables & GDP Correlation & Significance (bilateral) \\
\hline Trust in parliament & $0,753^{* *}$ & 0,000 \\
\hline Trust in the legal system & $0,795^{* *}$ & 0,000 \\
\hline Trust in the police & $0,793^{* *}$ & 0,000 \\
\hline Trust in politicians & $0,741^{* *}$ & 0,001 \\
\hline
\end{tabular}

Source: own elaboration with data from the World Bank, the ESS and the Eurobarometer

** Correlation is significant at level 0,01

$\star$ Correlation is significant at level 0,05

The results show that, overall, there is a strong association between GDP and items that measure citizens' trust in parliament, the legal system, the police, and politicians. All correlations are high, statistically significant, and positive: the higher the level of trust, the higher the GDP. Again, this relationship could also be worded by stating that citizens from high-GDP countries tend to trust their public organizations. In this case, no other items were available to examine other dimensions of trust, and here to some extent the prevailing performance-trust hypothesis, which posits that trust results from a positive assessment of governmental performance, may be applicable in the context of wealthy nations (Houston et al., 2016). But it could also be argued that more trustworthy public sector organizations are in a better position to make binding decisions, attract public resources, fulfill aims, and guarantee the fulfillment of public policies (Easton, 1975; Rudolph and Evans, 2005). 


\section{ELABORATING INDICATORS OF INTANGIBLE ASSETS}

In order to establish comparisons between intangible and tangible assets and among countries, it was explored whether indicators could derive from those variables identified for giving information about an intangible asset. Factor analysis is a statistical technique which reduces a set of data into few factors, being these factors independent from each other. For this research, factor analysis was carried out with the eight variables (items) found logically related with the concepts of engagement and trust. Varimax rotation method was used with Kaiser normalization, with a high explained variance of 90.4\% (see Annex 2 for details), the resulting factors are shown in Table 3).

Table 3. Factor analysis results

\begin{tabular}{lll}
\hline \multicolumn{1}{c}{ FACTOR 1 (coefficient) } & \multicolumn{1}{c}{ FACTOR 2 (coefficient) } & \multicolumn{1}{c}{ FACTOR 3 (coefficient) } \\
\hline \multicolumn{1}{c}{ TRUST } & \multicolumn{1}{c}{ POLITICAL ENGAGEMENT } & \multicolumn{1}{c}{ PUBLIC ENGAGEMENT } \\
\hline Trust in Legal System $(0,975)$ & Have worked in Political Parties $(0,934)$ & Have recycled $(0,963)$ \\
Trust in Politicians $(0,958)$ & Have contacted politicians $(0,671)$ & Have signed petitions $(0,570)$ \\
Trust in Parliament $(0,942)$ & & \\
Trust in Police $(0,813)$ & &
\end{tabular}

Source: Own elaboration with data from the World Bank, the ESS and the Eurobarometer

Three each-other independent components derived from factor analysis. The first factor includes all items asking about trust in different institutions (all of them have a high coefficient), and it looks reasonable to establish 'Trust' as a first component. The second factor grouped two variables ("having worked in political parties" and "having contacted politicians"), the two of them referring an explicit political behaviour, what lead to call this component 'Political Engagement'. The third and final factor grouped another two items ("Having recycled" and "Having signed petitions") which seemed to be measuring involvement or commitment with issues which were not specifically political, and thus this component was called 'Public Engagement'.

\section{COMPARING THE RELATION WITH WEALTH OF TANGIBLE AND OF INTANGIBLE CAPITAL}

Once indicators for intangible assets were found, the relation between growth and tangible assets on the one hand, and between growth and intangible assets on the other were compared, and results are shown in Table 4. It presents correlations between all countries' GDP on the one hand and variables relating to tangible capital (unemployment and inflation rates according to the World Bank data) and to intangible capital (the three factors which resulted from the factor analysis: 'Political Engagement', 'Public Engagement', and 'Trust') on the other. 
Table 4. Tangible/intangible capital and wealth (correlations)

\begin{tabular}{r|c|cccc}
\hline & \multicolumn{2}{c}{ Tangible capital } & Intangible capital & \\
\cline { 2 - 6 } & $\begin{array}{c}\text { Total } \\
\text { unemployment } \\
\text { (\% labor force) }\end{array}$ & Inflation (\%) & Trust & $\begin{array}{c}\text { Political } \\
\text { Engagement }\end{array}$ & $\begin{array}{c}\text { Public } \\
\text { Engagement }\end{array}$ \\
\hline GDP (per cápita) & $-0,270$ & $0,540^{*}$ & $0,779^{* *}$ & $0,835^{* *}$ & $0,681^{* *}$ \\
\hline
\end{tabular}

Source: own elaboration with data from the World Bank, the ESS and the Eurobarometer

$* *$ Correlation is significant at level 0,01

$*$ Correlation is significant at level 0,05

The results show, first, that both tangible and intangible capital have a relation with GDP. In the case of tangible capital, the correlation with the inflation rate is positive and, therefore, the higher it is, the higher the level of GDP. As is to be expected, the correlation with the unemployment rate is negative, so the higher the latter is, the lower GDP is; therefore, employment is positively associated with GDP. However, correlation between this variable and GDP is low and non-statistically significant.

For the three variables measuring intangible assets, correlations are positive, high and statistically significant, meaning that the higher trust, political engagement and public engagement, the higher GDP is. Comparatively, the relation between intangible capital with wealth seems to be higher than that of tangible capital: the correlations are higher (around more than thirty tenths) and more statistically significant. It seems that the findings presented by the World Bank in 2006 and 2011 are reflected in the results of this study: certain specific aspects of citizens' perceptions of public sector organizations regarding engagement and trust are more strongly associated with growth than tangible capital is. 


\section{COMPARING GROUPS OF COUNTRIES}

The comparison among countries was carried out by means of clustering according to the level of GDP. Table 5 shows the countries belonging to each group.

Table 5. Groups of countries according to GDP

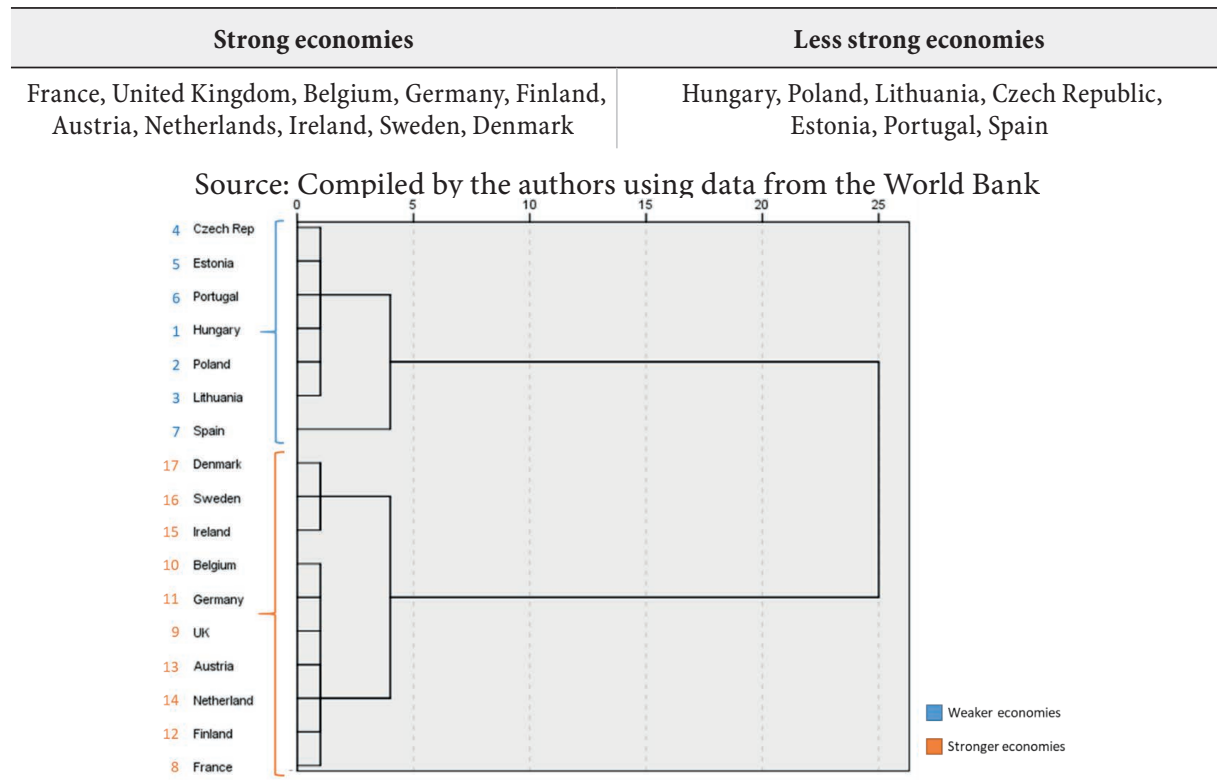

Note 1: These countries are numbered (left column) based on their GDP per capita. Thus, the one with the number 1 is the country with the lowest income per capita and the one with the number 17 is the country with the highest GDP per capita Note 2: The cluster analysis was performed with SPSS software

Table 6 contains the results of the comparison between clusters on the basis of the relationship between GDP on the one hand and tangible and intangible capital on the other.

Table 6. Tangible/intangible capital and wealth (correlations).

Cross-country groups' comparative data

\begin{tabular}{cccccc}
\hline & \multicolumn{2}{c}{ Tangible capital } & \multicolumn{2}{c}{ Intangible capital } \\
\hline & $\begin{array}{c}\text { Total } \\
\text { unemployment } \\
\text { (\% labor force) }\end{array}$ & Inflation (\%) & Trust & $\begin{array}{c}\text { Political } \\
\text { Engagement }\end{array}$ & $\begin{array}{c}\text { Public } \\
\text { Engagement }\end{array}$ \\
\hline $\begin{array}{c}\text { GDP stronger } \\
\text { economies }\end{array}$ & $-0,706^{*}$ & $-0,386$ & 0,602 & $0,706^{*}$ & $-0,222$ \\
\hline $\begin{array}{c}\text { GDP weaker } \\
\text { economies }\end{array}$ & $-0,361$ & 0,711 & $0,902^{* *}$ & 0,717 & 0,165 \\
\hline
\end{tabular}

Source: own elaboration with data from the World Bank, the ESS and the Eurobarometer

$* *$ Correlation is significant at level 0,01

* Correlation is significant at level 0,05 
Based on information from Table 6, it seems not to be possible to note the existence of a pattern that indicates that the association between intangible capital and wealth is different according to the level of the economy. In stronger economies, whereas the correlation is higher and significant with 'Political Engagement', no correlation appears to be between the other two variables that measure intangible value. In weaker economies a very high, positive and statistically significant relation is shown between GDP and 'Trust', but no correlation appears to be between GDP and the other indicators of intangible value. In any case, both for stronger economies and for weaker economies the relation between intangible capital and growth is higher than that between tangible capital and growth. Tables 7 and 8 show results for each specific item that compose the indicator.

Table 7. Engagement and GDP (correlations). Comparative data on cross-country clusters

\begin{tabular}{l|lcc}
\hline & \multicolumn{1}{c}{ Variables } & $\begin{array}{c}\text { GDP (stronger } \\
\text { economies) }\end{array}$ & $\begin{array}{c}\text { GDP (weaker } \\
\text { economies) }\end{array}$ \\
\hline $\begin{array}{l}\text { Expressions } \\
\text { of political } \\
\text { engagement }\end{array}$ & Having worked for a political party & 0,265 & $0,906^{* *}$ \\
\hline $\begin{array}{l}\text { Expressions of public } \\
\text { engagement }\end{array}$ & Having contacted a politician or government official & $0,699^{*}$ & $0,852^{*}$ \\
\cline { 2 - 4 } & Having signed petitions & $-0,039$ & $0,872^{*}$ \\
\hline & Having recycled & $-0,378$ & 0,409
\end{tabular}

Source: own elaboration with data from the World Bank, the ESS and the Eurobarometer

$* *$ Correlation is significant at level 0,01

${ }^{*}$ Correlation is significant at level 0,05

Table 8. Trust and GDP (correlations). Comparative data on cross-country clusters

\begin{tabular}{c|c|c}
\hline Variables & GDP (stronger economies) & GDP (weaker economies) \\
\hline Trust in parliament & 0,581 & 0,246 \\
\hline Trust in the legal system & $0,686^{*}$ & $-0,081$ \\
\hline Trust in the police & 0,536 & $0,885^{\star}$ \\
Trust in politicians & $0,656^{*}$ & $-0,233$
\end{tabular}

Source: own elaboration with data from the World Bank, the ESS and the Eurobarometer

** Correlation is significant at level 0,01

${ }^{*}$ Correlation is significant at level 0,05

Concerning 'Engagement', data for each specific item show that all items except 'having recycled' have a higher correlation (statistically significant) in weaker economies than in stronger economies; concerning 'Trust', no clear trend is shown, since in stronger economies there are high correlations in two of the four institutions measured, whereas in weaker economies only 'Trust in the police' seems to be correlated. 
Overall, it seems to be that the stronger correlation that is found between growth and intangible capital (as compared to that with tangible capital) does not behave differently in stronger economies than in weaker economies, does not support the part of the World Bank's findings that in rich countries wealth corresponds to intangible capital more than in less strong economies. The level of the economy, according to these research findings, does not make a difference for the relevance of the intangible capital.

\section{DISCUSSION}

Might communication play a role in the growth of a country? This question has been addressed via presenting another, which looks specifically at intangible assets: Do public sector intangible assets that are based on citizens' perceptions give access to tangible wealth? This research has sought to explore the "black box" that constitutes an important source of wealth: intangible capital. The analysis has focused on the relationship between GDP and public sector organizations' perceptions-based intangible capital, and it could be argued that in doing so, the social dimension of public management has been left out. This area has been considered elsewhere (see Canel and Luoma-aho, 2019) in the form of a discussion of the need to find the methods and measures that best allow the public sector to assess its impact in a way that includes social value. This paper suggests, however, that it is also very important to conduct research that places an economic value on intangible aspects of public sector organizations such as the quality of the relations that are built between the latter and citizens. This has been the aim of this study.

The analysis of aggregate data from 17 OECD countries consolidates the finding that intangible capital is a significant factor of wealth across countries. In this research, the variables that measure intangible capital strongly correlate with GDP, and all of them do so to a greater degree than the measurements of tangible capital correlate with GDP. It seems to be the case that the extent to which citizens trust their public institutions, or the degree to which they are prone to be engaged with said institutions, are factors that are more strongly associated with wealth than unemployment and inflation levels. The quality of institutions as perceived by citizens, which is an intangible asset, clearly matters when it comes to wealth.

This research makes it possible to state that the concept of intangible asset is a helpful construct for the purpose of conceptually and operationally disentangling and breaking down the possible sources of intangible capital and, hence, of wealth. It has identified some specific intangible assets that emerge within the relationship between citizens and public sector organizations. More specifically, 
it has provided measures for citizen-perception-based intangible assets such as engagement and trust.

Concerning engagement, data corroborate the relevance of this intangible resource for growth, and, based on factor analysis results that yielded two different components, allow differentiating the relation of political engagement from the relation of public engagement. Relation of both with GDP is high and positive, being the relation with political engagement slightly higher than with public engagement. Another finding of interest is that out of all forms of engagement, having worked for a political party is the one that is least strongly associated with high GDP. These results support the claim that measures of citizen engagement need to be developed to capture more social aspects of this asset (Dahlgren, 2009; Ekman and Amna, 2012), in order to identify and acknowledge a possible committed citizen who is politically independent, and who focuses on solidarity and on civil action (Dalton, 2008). This might suggest that public sector organizations should look for new forums in which people might be developing engaging practices. As data presented here indicate, these new forums are also efficient in terms of enabling access to tangible wealth.

Finally, trust is also strongly associated with GDP, suggesting either that wealthier citizens have a greater tendency to trust their public organizations or that trustworthy organizations generate wealth.

Regarding the comparison between the two GDP-based clusters of countries, the data are not clear and do not allow to establish a solid pattern that differentiates the behavior of intangible capital in stronger economies from that of weaker economies. It is notable, however, that trust is more clearly correlated with GDP among the group of strong economies, but the same is not true of less strong economies, with the exception of the measure of 'Trust in the police'. It might be the case that in these countries the lack of trustworthy public sector organizations means that none of these organizations is relevant for growth, except for police forces, which therefore become a major driver. But the opposite is shown concerning engagement: certain expressions of political engagement ('having worked for a political party' and 'having contacted a politician') and of public engagement ('having signed petitions') are highly correlated with GDP in weaker economies. This highlights the relevance of working in governmental programs of citizen engagement in these countries, since, according to these findings, they might have a positive relation with growth.

Ascertaining what actually drives citizens to be engaged is certainly an ongoing challenge for both researchers and public sector communication professionals; the findings presented here indicate that developing new studies that allow more precision in terms of the sources of engagement would be worthwhile.

This study does, of course, raise the question of causality, as has been pointed out all along the paper: Could it be that the higher a country's GDP, the better its 
organizations perform and, hence, the more they engage citizens or are trusted? This research has not explored causal relationships, and therefore at present opposing arguments may be made. One could argue that in wealthy countries citizens tend to trust public organizations, possibly because they attribute the country's high GDP to a well-performing public sector; but it could also be the case that more trustworthy public sector organizations make countries more productive and wealthier. Further research is needed to establish more precise causal relationships, but it is understood here that some policy consequences can be identified with the available data, as also implications for public sector communication.

\section{CONCLUSIONS: IMPLICATIONS FOR PUBLIC SECTOR COMMUNICATION}

Whatever the causal relationship may be, this paper concludes that both directions of interpretation provide an interesting hint for further research on the development of intangible resources in the public sector, as also for recommendations to improve public sector communication.

First, the findings presented here show an association between intangible resources and real wealth, and thus they support the argument that intangible assets derive from good practices and experiences and, as such, can be managed but not created from scratch. In other words, even citizen-perception-based intangible assets are not the result of a successful perceptions-management communication strategy alone; they need to be supported by facts. Any communication that aims at building these intangible assets should combine organizational behaviors with citizens' perceptions. This requires messages that stress actual achievements over the personality of the leader, and skilled leaders in crafting deeds-supported messages with which make citizens acknowledge actual strengths.

Second, since what has been shown is that the quality of institutions matters for wealth, public sector organizations should develop strategies to identify, build, maintain, and measure the black box's intangible assets, exploring the relationships between them and, ultimately, their relationships with society. This research findings underline the relevance that communication departments should be granted in order to improve relations between public sector organizations and citizens that, ultimately, derive in greater intangible resources, at least of those explored here, engagement and trust. Governmental programs of engagement and of trust should be developed in public sector organizations of democratic nations through cross-departmental relations that include the communication office, and this implies redesigning organizational charts.

Third, building perceptions-based intangible resources requires public sector communication that centers on listening instead of on selling, and that collects 
society's feedback to make sense of data about citizens' needs and expectations. It is only through ongoing interaction with different publics that engagement and trust can be built; it is this interaction what can provide useful insights about what are the standards according to which citizens are going to assess how trustful public leaders, policies and organizations are; and subsequently, whether to engage with them.

Finally, these research findings about the different relation that political forms of engagement (focused on influencing some political outcomes) have as compared to the relation of public forms of engagement (oriented to the benefit of the community) can illuminate the communication of governmental programs of citizen engagement. Citizens might be more prone to engage with public institutions when the benefits for public services are stressed over the political battles that are entangled in any public service deliverance. Communication professionals should develop skills better attuned to that kind of "apolitical" engagement.

There are important caveats to be made regarding this study. One is the limitations that are implied as to the nature of the intangible assets dealt with in this paper. Since they are perception based, the available data will always come from surveys. And data on facts-for instance, how people actually engage-would enrich the analysis of an important aspect of the asset. All efforts oriented to build consistent data that allow cross-country comparisons of actual behaviors would be welcomed. The issue of the inclusion of measures of social growth (and not only measures of the state of the economy) is also an important one. A deeper analysis of the impact of specific intangible assets on growth through comparisons of wealth across time is also required. Previous research suggests that significant and rapid institutional change, while not the norm, is feasible and does take place in practice (Kauffmann et al., 2005). A combination of intangible assets management and appropriate communication strategies could indeed improve the quality of organizations and hence make a difference to growth.

Strengthening democratic institutions via the building of specific intangible assets through communication will be wealth enhancing; and working on citizen-perception-based intangible assets will help to better calibrate the gaps between public sector organizations and citizens' needs and expectations. The latter will also make it possible to develop route maps for communicating to citizens what can be expected from a specific public policy and to design subsequent governmental actions. Ultimately, assessing social and economic growth, which is associated with the capacity of a specific government to build intangible assets (those of engagement and trust according to this research), will foster competitiveness among public administrations to provide public value to the society they serve. 


\section{ACKNOWLEDGEMENTS}

The authors would like to thank Tom Corkett for his extremely helpful and professional aid in the editing of the manuscript.

\section{REFERENCES}

Barrett, M., \& Brunton-Smith, I. (2014). Political and civic engagement and participation: Towards an integrative perspective. Journal of Civil Society, 10(1): 5-28.

Bouckaert, G., \& Van de Walle, S. (2001). Government performance and trust in government. In Paper for the Permanent Study Group of Productivity and Quality in the Public Sector at the EGPA Annual Conference. Vaasa, Finland, September 2001.

Bouckaert, G. (2012). Trust and public administration. Administration, 60(1): 91-115.

Brady, H. (1999). Political Participation. In: J. P. Robinson, P.R. Shaver \& L. S. Wrightsman (eds.), Measures of Political Attitudes. San Diego: Academic Press.

Bryson, J. M., Crosby, B. C., \& Stone, M. M. (2015). Designing and implementing cross $\$ sector collaborations: Needed and challenging. Public Administration Review, 75(5): 647-663.

Bovaird, T., \& Loeffler, E. (2012). From engagement to co-production: The contribution of users and communities to outcomes and public value. Voluntas: International Journal of Voluntary and Nonprofit Organizations, 23(4): 1119-1138.

Canel, M.J., Luoma-aho, V., \& Barandiarán, X. (2020). Public sector communication and public valuable intangible assets. In V. Luoma-aho \& M. J. Canel (eds.), Handbook of Public Sector Communication. Wiley-Blackwell.

Canel, M. J., \& Luoma-Aho, V. (2015). Crisis en la Administración Pública, oportunidad para la intangibilidad [Crisis in Public Administration, opportunity for intangibility]. In J. Villafañe (ed.), La comunicación empresarial y la gestión de los intangibles en España y Latinoamérica [Business communication and the management of intangibles in Spain and Latin America]. Madrid: Pearson.

Canel, M.J., \& Luoma-aho, V. (2019). Public Sector Communication. Closing Gaps between Citizens and Public Organizations. New Jersey: John Wiley and Sons.

Canel, M. J., Oliveira, E. S., \& Luoma-aho, V. (2017). Exploring citizens' judgments about the legitimacy of public policies on refugees: In search of clues for governments' communication and public diplomacy strategies. Journal of Communication Management, 21(4): 355-369.

Carmeli, A., \& Tishler, A. (2005). Perceived organizational reputation and organizational performance: An empirical investigation of industrial enterprises. Corporate Reputation Review, 8(1): 13-30.

Coursey, D., Yang, K., \& Pandey, S. K. (2012). Public service motivation (PSM) and support for citizen participation: A test of Perry and Vandenabeele's reformulation of PSM theory. Public Administration Review, 72(4): 572-582.

Dahlgren, P. (2009). Media and political engagement: Citizens, communication, and democracy. Cambridge: Cambridge University Press. 
Denhardt, J. V., \& Denhardt, R. B. (2015). The new public service revisited. Public Administration Review, 75(5): 664-672.

Easton, D. (1975). A re-assessment of the concept of political support. British Journal of Political Science, 5(4): 435-457.

Ekman, J., \& Amnå, E. (2012). Political participation and civic engagement: Towards a new typology. Human affairs, 22(3): 283-300.

Fledderus, J., Brandsen, T., \& Honingh, M. E. (2015). User co-production of public service delivery: An uncertainty approach. Public Policy and Administration, 30(2): 145-164.

Font, J., \& Navarro, C. (2013). Personal experience and the evaluation of participatory instruments in Spanish cities. Public Administration, 91(3): 616-631.

Fung, A. (2015). Putting the public back into governance: The challenges of citizen participation and its future. Public Administration Review, 75(4): 513-522.

James, O. (2009). Evaluating the expectations disconfirmation and expectations anchoring approaches to citizen satisfaction with local public services. Journal of Public Administration Research and Theory, 19(1): 107-123.

James, O. (2010). Performance measures and democracy: Information effects on citizens in field and laboratory experiments. Journal of Public Administration Research and Theory, 21(3): 399-418.

James, O. (2011). Managing citizens' expectations of public service performance: evidence from observation and experimentation in local government. Public Administration, 89(4): 1419-1435.

James, O., \& Moseley, A. (2014). Does performance information about public services affect citizens' perceptions, satisfaction, and voice behaviour? Field experiments with absolute and relative performance information. Public Administration, 92(2): 493-511.

Heikkila, T., \& Isett, K. R. (2007). Citizen involvement and performance management in special purpose governments. Public Administration Review, 67(2): 238-248.

Houston, D. J., Aitalieva, N. R., Morelock, A. L., \& Shults, C. A. (2016). Citizen trust in civil servants: a cross-national examination. International Journal of Public Administration, 39(14): 1203-1214.

Luoma-aho, V. (2008). Sector reputation and public organisations. International Journal of Public Sector Management, 21(5): 446-467.

Oomsels, P., \& Bouckaert, G. (2014). Studying Interorganizational Trust in Public Administration: A Conceptual and Analytical Framework for Administrational Trust. Public Performance \& Management Review, 37(4): 577-604.

Oomsels, P., Callens, M., Vanschoenwinkel, J., \& Bouckaert, G. (2019). Functions and dysfunctions of interorganizational trust and distrust in the public sector. Administration \& Society, 51(4): 516-544.

Putnam, R. (1995). Bowling Alone: America’s Declining Social Capital. Journal of Democracy, 6 (1): 65-78.

Rudolph, T. J., \& Evans, J. (2005). Political trust, ideology, and public support for government spending. American Journal of Political Science, 49(3): 660-671.

Sanders, K., \& Canel, M. J. (2015). Mind the gap: Local government communication strategies and Spanish citizens' perceptions of their cities. Public Relations Review, 41(5): 777-784.

Scott, RW, \& J.W. Meyer. (1991). The Organization of Societal Sectors: Propositions and Early Evidence. In: W.W. Powell \& P.J. Di Maggio (eds.), The New Institutionalism in Organizational Analysis. Chicago, Il: University of Chicago Press. 
Teorell, J., Torcal, M., \& Montero, J. R. (2007). Political participation: Mapping the terrain. Citizenship and involvement in European democracies: A comparative perspective, 17: 334-357.

Van de Walle, S., \& Bouckaert, G. (2003). Public service performance and trust in government: the problem of causality. International Journal of Public Administration, 26(8-9): 891-913.

Yang, K., \& Pandey, S. K. (2011). Further dissecting the black box of citizen participation: When does citizen involvement lead to good outcomes? Public Administration Review, 71(6): 880-892.

Van de Walle, S. (2007). Determinants of Confidence in the Civil Service: An International Comparison. Research in Public Policy Analysis and Management 16. Emerald Group Publishing Limited.

Wang, X., \& Wan Wart, M. (2007). When public participation in administration leads to trust: An empirical assessment of managers' perceptions. Public Administration Review, 67(2): 265-278.

World Bank (2006). Where is the wealth of nations? Measuring capital for the 21st. Washington, DC: World Bank.

World Bank (2011). The changing wealth of nations: Measuring sustainable development in the new millennium. Washington, DC: World Bank.

World Bank. (2013). “Data Catalog”. Retrieved January 7, 2016 from https://datacatalog.worldbank. org/rule-law-estimate.

\begin{tabular}{|c|c|c|c|c|c|c|c|c|c|c|c|}
\hline & \multirow{3}{*}{ GDP $p / c$} & \multicolumn{4}{|c|}{ ENGAGEMENT } & \multicolumn{4}{|c|}{ TRUST } & \multicolumn{2}{|c|}{ Tangible capital } \\
\hline & & $\begin{array}{l}\text { Worked } \\
\text { political } \\
\text { party }\end{array}$ & $\begin{array}{l}\text { Contacted } \\
\text { Politicians }\end{array}$ & $\begin{array}{l}\text { Signed } \\
\text { Petitions }\end{array}$ & Recycling & $\begin{array}{c}\text { Trust } \\
\text { Parliament }\end{array}$ & $\begin{array}{l}\text { Trust Legal } \\
\text { System }\end{array}$ & Trust Police & $\begin{array}{c}\text { Trust } \\
\text { Politicians }\end{array}$ & Unemployment & Inflaction \\
\hline & & yes $(\%)$ & yes $(\%)$ & yes (\%) & yes $(\%)$ & 1 to 10 & 1 to 10 & 1 to 10 & 1 to 10 & (\% labor force) & $(\%)$ \\
\hline (AT) Austria & 51322,6 & 6 & 19 & 28 & 75 & 3,9 & 5 & 6,5 & 3,4 & 5,6 & 1,6 \\
\hline (BE) Belgium & 47439,3 & 4 & 14 & 23 & 81 & 4,8 & 5 & 6 & 4,1 & 8,5 & 0,3 \\
\hline (CZ) Czech Republic & 19744,5 & 2 & 9 & 17 & 78 & 3,9 & 4,7 & 5,7 & 3,3 & 6,1 & 0,3 \\
\hline (DE) Germany & 47902,6 & 4 & 17 & 36 & 76 & 5 & 5,7 & 6,7 & 3,8 & 5 & 0,9 \\
\hline (DK) Denmark & 62425,5 & 4 & 21 & 30 & 60 & 5,9 & 7,4 & 7,7 & 4,9 & 6,6 & 0,6 \\
\hline (EE) Estonia & 19941,4 & 4 & 14 & 10 & 56 & 4,4 & 5,2 & 6,1 & 3,5 & 7,4 & $-0,1$ \\
\hline (ES) Spain & 29600,4 & 8 & 16 & 32 & 74 & 3,7 & 4 & 6,3 & 2,2 & 15,9 & $-0,2$ \\
\hline (FI) Finland & 49914,6 & 5 & 19 & 32 & 75 & 5,5 & 6,7 & 7,9 & 4,6 & 8,7 & 1 \\
\hline (FR) Francia & 42955,2 & 5 & 16 & 38 & 82 & 4 & 5,1 & 6,1 & 2,8 & 10,3 & 0,5 \\
\hline (UK) United Kindong & 46412,1 & 3 & 19 & 40 & 79 & 4,3 & 5,5 & 6,3 & 3,5 & 6,1 & 1,5 \\
\hline (HU) Hungary & 14117,9 & 0 & 9 & 5 & 64 & 3,8 & 4,6 & 5,3 & 2,9 & 7,7 & $-0,2$ \\
\hline (IE) Ireland & 55503,3 & 5 & 19 & 25 & 84 & 3,8 & 5,3 & 6,3 & 3,3 & 11,9 & 0,2 \\
\hline (LT) Lithuania & 16554,9 & 4 & 10 & 6 & 62 & 3,2 & 4,3 & 5,5 & 3 & 10,7 & 0,1 \\
\hline (NL) Netherlands & 52157,4 & 4 & 18 & 29 & 80 & 5,1 & 5,9 & 6,4 & 4,8 & 7,4 & 1 \\
\hline (PL) Poland & 14341,6 & 2 & 8 & 14 & 69 & 2,8 & 3,5 & 5,1 & 2 & 9 & 0,1 \\
\hline (PT) Portugal & 22077,5 & 5 & 15 & 15 & 71 & 3,1 & 3,7 & 5,7 & 2 & 13,9 & $-0,3$ \\
\hline (SE) Sweden & 59180,1 & 6 & 19 & 47 & 86 & 6,2 & 6,4 & 6,9 & 5 & 8 & $-0,2$ \\
\hline
\end{tabular}

\section{ANNEX 2. TOTAL VARIANCE EXPLAINED WITH THE ANALYSIS OF MAIN COMPONENTS}

\begin{tabular}{|c|c|c|c|c|c|c|c|c|c|}
\hline \multirow{2}{*}{ 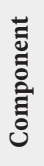 } & \multicolumn{3}{|c|}{ Auto initial values } & \multicolumn{3}{|c|}{$\begin{array}{l}\text { Sums of removal } \\
\text { of loads squared }\end{array}$} & \multicolumn{3}{|c|}{$\begin{array}{l}\text { Sums of rotation } \\
\text { of squared charges }\end{array}$} \\
\hline & Total & $\begin{array}{c}\% \text { of } \\
\text { variance }\end{array}$ & $\begin{array}{c}\% \\
\text { accumulated }\end{array}$ & Total & $\begin{array}{c}\% \text { of } \\
\text { variance }\end{array}$ & $\begin{array}{c}\% \\
\text { accumulated }\end{array}$ & Total & $\begin{array}{c}\% \text { of } \\
\text { variance }\end{array}$ & $\begin{array}{c}\% \\
\text { accumulated }\end{array}$ \\
\hline 1 & 4,817 & 60,207 & 60,207 & 4,817 & 60,207 & 60,207 & 3,894 & 48,670 & 48,670 \\
\hline
\end{tabular}


EXPLORING CITIZENS' PERCEPTIONS-BASED INTANGIBLE RESOURCES IN THE PUBLIC SECTOR...

\begin{tabular}{|c|c|c|c|c|c|c|c|c|c|}
\hline \multirow{2}{*}{ 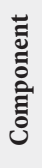 } & \multicolumn{3}{|c|}{ Auto initial values } & \multicolumn{3}{|c|}{$\begin{array}{l}\text { Sums of removal } \\
\text { of loads squared }\end{array}$} & \multicolumn{3}{|c|}{$\begin{array}{l}\text { Sums of rotation } \\
\text { of squared charges }\end{array}$} \\
\hline & Total & $\begin{array}{c}\% \text { of } \\
\text { variance }\end{array}$ & $\begin{array}{c}\% \\
\text { accumulated }\end{array}$ & Total & $\begin{array}{c}\% \text { of } \\
\text { variance }\end{array}$ & $\begin{array}{c}\% \\
\text { accumulated }\end{array}$ & Total & $\begin{array}{c}\% \text { of } \\
\text { variance }\end{array}$ & $\begin{array}{c}\% \\
\text { accumulated }\end{array}$ \\
\hline 2 & 1,557 & 19,772 & 79,979 & 1,582 & 19,772 & 79,979 & 1,980 & 24,752 & 72,423 \\
\hline 3 & 0,836 & 10,449 & 90,428 & 0,836 & 10,449 & 90,428 & 1,360 & 17,006 & 90,428 \\
\hline 4 & 0,409 & 5,117 & 95,545 & & & & & & \\
\hline 5 & 0,222 & 2,776 & 98,321 & & & & & & \\
\hline 6 & 0,085 & 1,061 & 99,382 & & & & & & \\
\hline 7 & 0,031 & 0,288 & 99,769 & & & & & & \\
\hline 8 & 0,018 & 0,231 & 100,000 & & & & & & \\
\hline
\end{tabular}

Note: With the distribution of the variables in 3 factors, the $90,42 \%$ of the total variance is explained 